\title{
Analysis of the Presence of Romanian Listed Companies in Tax Havens
}

\author{
Mihai-Bogdan Afrăsinei, Iuliana Eugenia Georgescu and Mircea Georgescu \\ Faculty of Economics and Business Administration, Alexandru Ioan Cuza \\ University of laşi, Iaşi, Romania
}

Correspondence should be addressed to: Mihai-Bogdan Afrăsinei; bogdan.afrasinei@yahoo.com

Received date: 3 April 2015; Accepted date: 10 August 2015; Published date: 19 September 2016

Copyright (C) 2016. Mihai-Bogdan Afrăsinei, luliana Eugenia Georgescu and Mircea Georgescu.

Distributed under Creative Commons CC-BY 4.0

\begin{abstract}
Tax havens are one of the most effective solutions in fighting taxation. In the context of international tax optimisation, almost all major companies in the world have subsidiaries or affiliates in such offshore jurisdictions. Similar studies conducted in other countries show that over a third of the companies listed on stock exchange have links to tax havens. The purpose of this paper is to analyse the presence of Romanian companies listed on the Bucharest Stock Exchange in tax havens. In order to achieve this goal, we analysed the annual reports for 2013 of a sample of 80 Romanian publicly traded companies. The results emphasize that $36 \%$ of the Romanian listed companies had links to 16 tax havens in 2013. Also, approximately 23\% (88 companies) of their overseas affiliates were incorporated in tax havens in 2013. Most of the companies with links to tax havens are operating in the industry sector.
\end{abstract}

Keywords: tax havens, international tax planning, offshore finance, multinational companies

\section{Introduction}

In recent years, offshore companies and tax havens have been in the center of many financial scandals, both nationally and internationally. Also, the press reports daily such cases involving numerous companies and businessmen, but also politicians, athletes, actors and other celebrities. If we appeal to a famous statement of Leona Helmesey, which argued that "only the little people pay taxes" (The Economist, 2001), we can say that tax havens are only for the powerful people.
Undoubtedly, the subject of offshore economy is perhaps now, more than ever, the focus of attention of both the public and the authorities. A possible explanation can be given by "the sheer size of the phenomenon" and by the fact that one third of foreign direct investments of multinational companies are turning to tax havens jurisdictions (Palan, 2009).

In the context of international tax planning, tax havens and offshore companies have become increasingly important and represent one of the most effective solutions in fighting taxation. Palan et al (2010) state that nowadays, a company (not necessarily multinational) without

Cite this Article as: Mihai-Bogdan Afrăsinei, Iuliana Eugenia Georgescu and Mircea Georgescu (2016)," Analysis of the Presence of Romanian Listed Companies in Tax Havens", Journal of Eastern Europe Research in Business and Economics , Vol. 2016 (2016), Article ID 187734, DOI: 10.5171/2016.187734 
links to tax havens that do business internationally is becoming increasingly rare.

It would be wrong to believe that in tax havens everyone benefits from extremely low rates of taxation or exemption from their payment. Tax havens practice a different treatment regarding the taxation of residents and non-residents, practice known in the literature as the "ring fencing". Thus, while non-residents enjoy a tax refuge in return for payment only of some registration and renewal fees, residents do not have the same privileges and are fully taxed (Palan et al, 2010). Moreover, "the ring fencing of fiscal schemes" is considered a fundamental characteristic of tax havens (Hampton and Christensen, 2002). Also, Shaxson (2012) believes that without the tax havens multinational companies would never have became so developed and powerful, while Deneault (2011) sees in tax havens a political issue.

\section{Literature Review}

In this globalised economy, governments from many countries are trying to provide favorable tax regimes to non-residents, while investors seek the best conditions for incorporating a business in which prevails, of course, the level of taxes (Quintard, 2010). That is why, some authors (Desai et al, 2005) consider that tax havens determine and accelerate the tax competition between governments in an attempt to attract mobile foreign investments.

Since there is no standard definition of what constitutes a tax haven, we find that one of the most common definitions in the literature is the one given by OECD (Slemrod and Wilson, 2009; Johnson and Holub, 2004; Preuss, 2010; Killian, 2006; Gravelle, 2015).

Within the "Harmful tax competition" initiative of the Organisation for Economic Co-operation and Development (OECD, 1998a), tax havens can be identified based on four main criteria: (a) are jurisdictions that do not charge any taxes or only nominal taxes; (b) is unlikely to share information with tax authorities from other countries; (c) are characterised by lack of transparency and (d) the hosted companies are not engaged in substantial activities in the jurisdiction. Through a similar approach, Larudee (2009) defines tax havens and offshore financial centers as jurisdictions that provide two things: zero or near-zero tax rates and secrecy for financial assets. However, Preuss (2012) underlines that tax havens provide tax incentives only for those gains arising outside the jurisdiction and even stipulates that activities carried out in the tax haven must not be substantial. Therefore, most tax havens are used only as a front in the development of complex tax optimisation strategies.

According to Champpell (1985), a tax haven is any foreign country that does not impose any tax or a very small tax for certain categories of income. Moreover, the same author adds that any country may be a tax haven for residents of other countries.

In another sense, Shaxson (2012) believes that tax havens are places that offer politically stable facilities to help companies and individuals get around the rules, laws and regulations of other jurisdictions, in order to attract financial capital. In other words, tax havens are trying to undermine other countries (Lesage and McNaird, 2011).

As in the case of defining tax havens, there is no standard definition of what is an offshore company. According to Hadnum (2013), an offshore company can be any non-resident company registered in a lowtax jurisdiction in order to avoid taxes both in this place, but especially in the country of origin.

In accordance with Cornez (2000), the term "offshore" does not necessarily refer to a different country; it can also be only outside the range of the taxation from the same country of residence.

However, we are not going to insist on defining these concepts, although there can be made entire papers on this topic. 
Although relatively simple at first glance, the subject is quite complex.

Corporate tax avoidance is a practice used worldwide. The most severe consequences are seen in the case of the developing countries. The government revenues are vital for their development (Brock, 2011). However, the purpose of tax havens is to attract companies and rich individuals from both developing and developed countries (Lesage and McNaird, 2011).

The latest estimates show that in developing countries, the contributions to government budgets of foreign affiliates of multinationals are approximately 730 billion USD per year, of which 220 billion USD represent corporate income taxes. It is estimated that 100 billion USD are lost every year from taxes through direct investments in tax havens (UNCTAD, 2015).

Although international organisations have put pressure on tax havens to be more transparent, few things have changed. For example, Kudrle (2009) conducted a study through which he tried to examine whether blacklisting some countries (38) by OECD decreased financial activity through tax havens. The results show, however, that there was no significant impact.

Sikka (2008) states that some of the large companies have become so powerful and influential that they can afford to put pressure on governments and to impose special conditions concerning their taxation. These companies are using social impact and threaten to move to other countries if the conditions required are not fulfilled.

\section{Background and Framework for analysis}

The use of tax havens is a widespread phenomenon all over the world. U.S. General Accountability Office (2004) was one of the first organisations which conducted a survey even since 2004 on the use of tax havens by US companies listed on the stock exchange. Then, the results showed that 59 of the 100 US companies had subsidiaries in tax havens. Subsequently, based on this model, similar studies have been undertaken in the UK, France or Spain. Also, nine years later in the United States a new study was conducted by US PIRG (Smith, 2013), using the same methodology to reflect the situation at that time. According to the study, in 2012 in the United States, the number of companies with subsidiaries in tax havens increased to 82 . In the $U K$, the number of companies having affiliates in tax havens is higher (98 of 100), as shown by the data published by ActionAid (2011). In France and Spain, however, the percentage of listed companies that have subsidiaries or affiliates in tax havens is huge. Not less than $100 \%$ of the listed companies use tax havens in France (Chavagneux and Rinuy, 2009) and 94\% in Spain (Observatorio de RSC, 2012). 
Table 1: Evidence of the use of tax havens in other countries

\begin{tabular}{|c|c|c|c|}
\hline UK & USA & France & Spain \\
\hline $\begin{array}{l}\text { A study conducted by } \\
\text { ActionAid (2011) on } \\
\text { the } 100 \text { biggest groups } \\
\text { (FTSE 100) listed on } \\
\text { the London Stock } \\
\text { Exchange emphasizes } \\
\text { that } 98 \text { of them have } \\
\text { affiliates in tax havens. }\end{array}$ & $\begin{array}{l}\text { A study on the } 100 \\
\text { largest American } \\
\text { listed companies } \\
\text { conducted by US PIRG } \\
\text { (Smith, 2013) } \\
\text { emphasizes that } 82 \text { of } \\
\text { them have } \\
\begin{array}{l}\text { subsidiaries in tax } \\
\text { havens. }\end{array}\end{array}$ & $\begin{array}{l}\text { A study conducted by } \\
\text { Alternatives } \\
\text { Economiques } \\
\text { (Chavagneux and } \\
\text { Rinuy, 2009) on the } 40 \\
\text { biggest companies } \\
\text { (CAC 40) listed on } \\
\text { Euronext Paris } \\
\text { emphasizes that they } \\
\text { all have subsidiaries in } \\
\text { tax havens. }\end{array}$ & $\begin{array}{l}\text { A study conducted by } \\
\text { Observatorio RSC } \\
(2012) \text { on the } \\
\text { companies listed on } \\
\text { Spain's } \\
\text { exchange shows that } \\
33 \text { of } 35 \text { firms use tax } \\
\text { havens. }\end{array}$ \\
\hline $\begin{array}{l}98 \% \text { of the analysed } \\
\text { companies use tax } \\
\text { havens. }\end{array}$ & $\begin{array}{l}82 \% \text { of the analysed } \\
\text { companies use tax } \\
\text { havens. }\end{array}$ & $\begin{array}{l}100 \% \text { of the analysed } \\
\text { companies use tax } \\
\text { havens. }\end{array}$ & $\begin{array}{l}94 \% \text { of the analysed } \\
\text { companies use tax } \\
\text { havens. }\end{array}$ \\
\hline $\begin{array}{l}\text { The analysed } \\
\text { companies have } 8492 \\
\text { affiliated entities in tax } \\
\text { havens. }\end{array}$ & $\begin{array}{l}\text { The analysed } \\
\text { companies have } 2686 \\
\text { subsidiaries in tax } \\
\text { havens. }\end{array}$ & $\begin{array}{l}\text { The analysed } \\
\text { companies have } 1470 \\
\text { affiliates in tax havens. }\end{array}$ & $\begin{array}{l}\text { The analysed } \\
\text { companies have } 449 \\
\text { subsidiaries in } 17 \text { tax } \\
\text { havens. }\end{array}$ \\
\hline $\begin{array}{l}\text { The most popular tax } \\
\text { havens are: Delaware, } \\
\text { Netherlands, Ireland, } \\
\text { Jersey, Hong Kong and } \\
\text { Cayman Islands. }\end{array}$ & $\begin{array}{l}\text { The most popular tax } \\
\text { havens are: Cayman } \\
\text { Islands, Netherlands, } \\
\text { Luxembourg, Ireland } \\
\text { and Hong Kong. }\end{array}$ & $\begin{array}{l}\text { The most popular tax } \\
\text { havens are: } \\
\text { Netherlands, } \\
\text { Switzerland, } \\
\text { Luxembourg, } \\
\text { Singapore, Ireland and } \\
\text { Hong Kong. }\end{array}$ & $\begin{array}{l}\text { The most popular tax } \\
\text { havens are: Delaware, } \\
\text { Netherlands, } \\
\text { Luxembourg and } \\
\text { Ireland. }\end{array}$ \\
\hline
\end{tabular}

Source: Own compilation based on data from ActionAid (2011), US Pirg (Smith, 2013), Alternatives Economiques (2009) and Observatorio de RSC (2012)

These evidences and the concern expressed in Romania and worldwide regarding the refuge of companies in tax havens have constituted the motivation to conduct our study.

The main hypothesis from which we start our research is that Romanian listed companies use tax havens, but at a much lower level than in UK, USA, France and Spain. Given the small size of companies and the fact that few are multinational, we expect to find fewer subsidiaries and related parties in tax havens.

\section{Research Methodology}

Having as starting point the level of use of tax havens by listed companies in USA, UK, France and Spain (as we have shown in Table 1), the purpose of this paper is to analyse the presence of Romanian companies listed on the Bucharest Stock Exchange (BSE) in tax havens.

The target population is represented by the 80 Romanian companies listed on the BSE in 2013. Moreover, so far, 2013 is the last year for which were published annual financial reports of companies. From the target population we have not eliminated any company, so the sample contains the same number of companies (80). Therefore, the data source is represented by the annual financial reports of companies for 2013 published on the website of BSE (www.bvb.ro).

During the first phase, we should mention under what aspects can be considered the presence of the analysed companies in tax havens. Companies may be present in tax havens through: (1) shareholders; (2) subsidiaries or (3) other related parties. 
Thus, to achieve the goal, we will analyse separately these related parties, after which we will compile the results. This approach requires an analysis of the following documents from the annual reports: "individual annual financial statements", "annual consolidated financial statements", "notes to the financial statements" and "director's reports". In order to identify the shareholders, we have studied within these documents the shareholder structure and the equity. In order to identify the subsidiaries we studied the shareholdings sections and the consolidated financial statements. In order to identify other related parties, we analysed the sections of the above mentioned documents that contain information about related parties and transactions with them. In addition to that, some of the companies mentioned in a separate document all related parties, while other companies just mentioned related parties with whom transactions have been completed. Also, not all companies mention the country of registration of related parties in the annual financial reports. In order to identify their country of origin, we looked for this information on the BSE website, on the companies' websites and carried Internet searches.

As for defining the "tax haven" concept, there is no standard list of jurisdictions that can be considered tax havens. There are numerous delimitations made in this regard by national and international organisations or scholars, such as: Organisation for Economic Co-operation and Development (1998b), International Monetary Fund (2000), Dharmapala and Hines (2006), Tax Justice Network (2007) and U.S. Government Accountability Office (2008). We will use the same list as in the study "Addicted to tax havens: The secret life of the FTSE 100" performed by ActionAid in 2011.

Further, we intend to identify the shareholders of companies listed on the BSE which are resident in tax havens.

\section{Analysis of shareholders}

During this analysis, we searched for resident corporate shareholders, foreign corporate shareholders, resident individual shareholders, foreign individual shareholders and the Romanian stateowned shares. At some companies, we found reporting expressions such as "other legal persons shareholders", "other individual shareholders", "other shareholders" or simply "others". These shareholders are usually list-type shareholders or insignificant shareholders for whom we were not able to determine their country of origin or legal form.

Analysing the companies listed on the BSE, we identified that $46.44 \%$ of the capital of these companies is owned by Romanian shareholders, while foreign capital has a share of $30.26 \%$. Also, we notice that the tax havens shareholders own $14.66 \%$ of shares in the analysed companies. We note that in our study we treated separately the foreign shareholders and the shareholders from tax havens. A quite large percentage $(30.26 \%)$ is owned by the list-type or insignificant shareholders which were not mentioned in shareholder structure and for whom we were not able to determine the country of origin or their legal form. For example, 5 of the 7 listed financial companies have in the shareholder structure "other shareholders" with 100\%. These companies are SIF Banat Crisana, SIF Moldova, SIF Muntenia, SIF Oltenia and SIF Transilvania. Another financial investment company, SSIF Broker, has 54\% of the shareholders in the category "others". Also, in the domestic participation we included Romanian shares held by the Romanian state. These results are shown in Figure 1.

In Figure 2, we highlighted the participation of shareholders in absolute values. We made the conversion of the capital value from the national currency (LEI) in US Dollar (USD) using the National Bank of Romania exchange rate on 31.12.2013 (1 USD = 3.2551 RON). The analysis results show that in absolute values the Romanian participation is the highest (about 3.5 billion USD), while the foreign holding is approximately of 997

Mihai-Bogdan Afrăsinei, Iuliana Eugenia Georgescu and Mircea Georgescu(2015),Journal of Eastern Europe Research in Business and Economics, DOI:10.5171/2015.187734 
million USD, while the participation from tax havens is approximately of 845 million USD. We note that compared to the situation from Figure 1, the interests held by list-type and insignificant shareholders

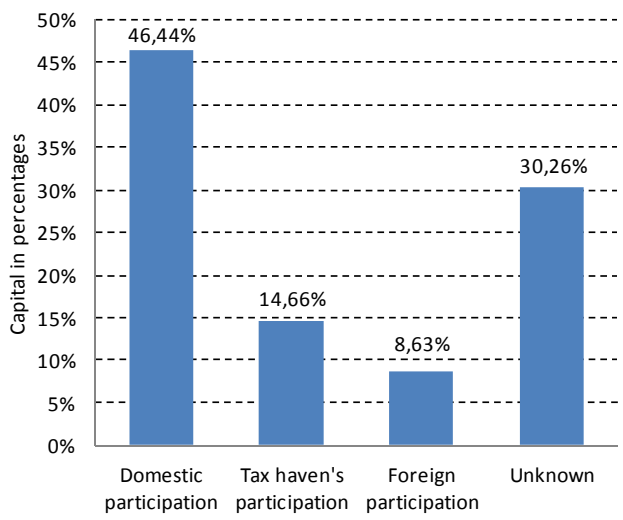

Figure 1: The contribution in percentages of shareholders to the capital of the Romanian listed companies according to their country of origin in 2013

\section{Source: own processing}

In Figure 3, we highlighted the contribution in the capital in relative values by type of shareholders. Thus, we notice that the largest share is held by corporate shareholders (58\%), followed by insignificant shareholders who could not be identified (17\%). Individual shareholders own a share of $16 \%$, while the Romanian State owns only $8 \%$ although it has shares in 18 listed companies.

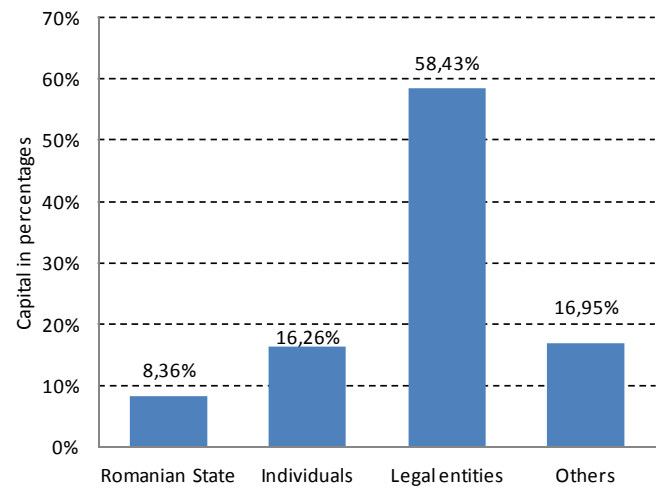

Figure 3: The contribution in percentages of shareholders to the capital of the Romanian listed companies by shareholders type in 2013 Source: own processing for which we could not determine the country of origin is only 634 million USD. Typically, this category includes individuals.

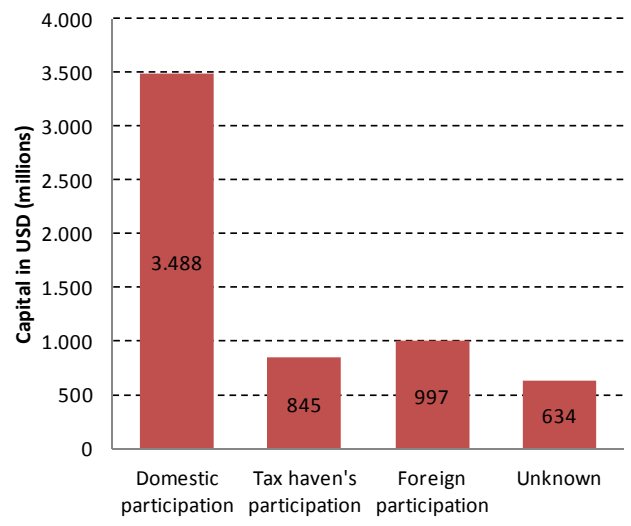

Figure 2 :The contribution in USD of shareholders to the capital of the Romanian listed companies according to their country of origin in 2013

\section{Source: own processing}

If we relate to the shares in absolute values (USD), we notice some significant differences. Thus, Figure 4 shows that legal entities have the largest part of the capital (approximately 2.7 billion USD), while the Romanian state has a close value (about 2.6 billion USD). Insignificant shareholders that could not be identified hold interests of approximately 530 million USD, while individuals own only 139 million USD.

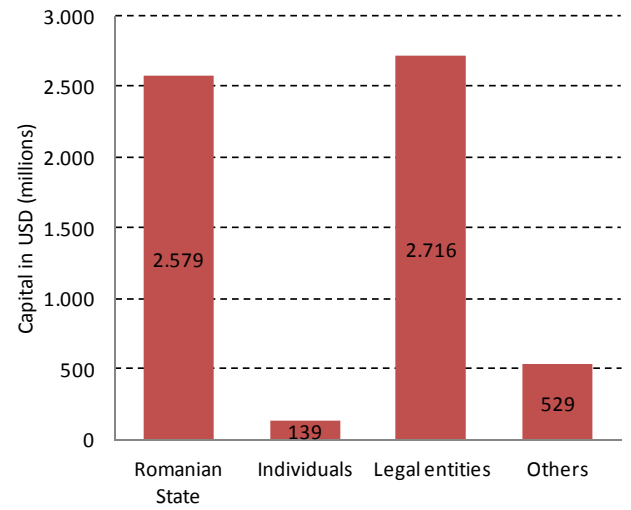

Figure4: The contribution in USD of shareholders to the capital of the Romanian listed companies by shareholders type in 2013 Source: own processing 
We identified a total of 52 foreign shareholders of which 38 are incorporated in tax havens. As country of origin, most foreign shareholders of companies listed on the BSE in 2013 are in Cyprus (18 shareholders), the Netherlands (6 shareholders) and Luxembourg (5 shareholders), all three countries being listed as tax havens. This is shown in Figure 5 , where it can be seen that there are also shareholders from other tax havens such as the British Virgin Islands (3), Cayman Islands (3), Belize (2) and Switzerland (1), but fewer. If we consider only the shareholders from Cyprus, the Netherlands and Luxembourg, we find that they are approximately $55 \%$ of the total number of shareholders. Basically more than half of the foreign shareholders are registered in tax havens (73\%).

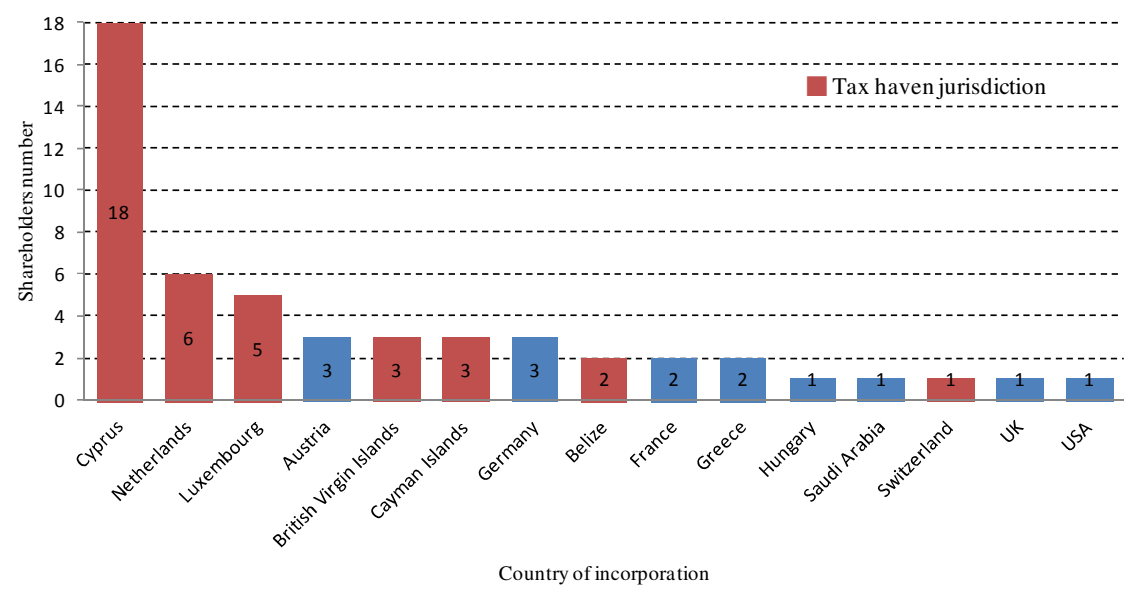

Figure 5: Foreign shareholders of the Romanian listed companies according to their country of origin in 2013

\section{Source: own processing}

\section{Analysis of subsidiaries}

The second stage of the research is represented by the analysis of the subsidiaries of Romanian listed companies. Subsidiaries are entities controlled by the company with over $50 \%$ of the voting rights.

The results highlighted in Figure 6 show that only 43 of the 80 analysed companies have subsidiaries. All these companies have at least one subsidiary in Romania, 9 of the companies have subsidiaries abroad, while only 3 companies have subsidiaries in tax havens.

We conclude that the number of companies with subsidiaries in tax havens is insignificant. If we refer to the case of USA, UK, Spain and France, the difference is enormous. A possible explanation may be given based on the opinion of Löpfe and
Vontobel (2013) which emphasizes that companies that previously represented a "pride of a region" have now become just supply chains in a group in which cost optimisation and tax planning has become the main objectives. In Romania, internationally famous companies before 1990 have now become subsidiaries of foreign companies (most from tax havens). In addition to that, the analysed companies do not need subsidiaries in tax havens for tax optimisation as they have shareholders and other related parties in tax havens. This may be the reason why these companies have much more shareholders registered in tax havens (24 companies have shareholders in tax havens) than subsidiaries (3 companies have subsidiaries in tax havens). 


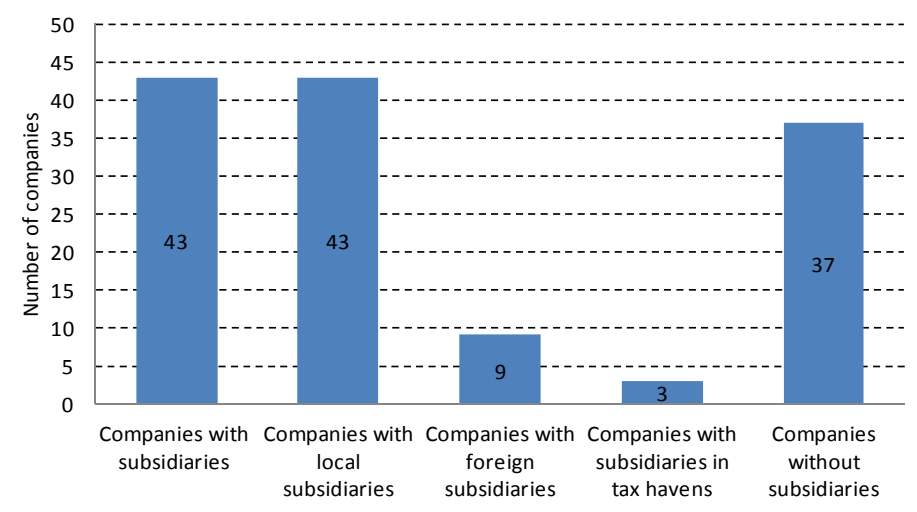

Figure 6: The number of Romanian listed companies with subsidiaries by Country of origin in 2013

\section{Source: own processing}

Figure 7 reveals that most foreign subsidiaries are incorporated in Ukraine (3), Austria (2), Bulgaria (2), Cyprus (2), France (2), Germany (2), Kazaksthan (2) and Republic of Moldavia (2). In tax havens, only four subsidiaries are registered: two subsidiaries in Cyprus, one subsidiary in British Virgin Islands and one subsidiary in Isle of Man. The companies with subsidiaries in tax havens are OMV Petrom (2), Romcarbon SA (1) and SIF Banat Crisana (1).

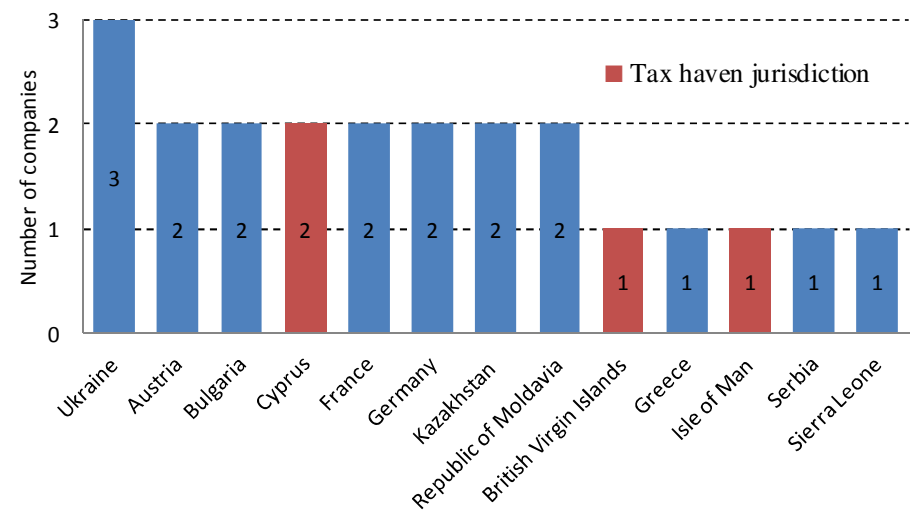

Figure 7: The number of subsidiaries of Romanian listed companies by Country of origin in 2013

\section{Source: own processing}

The companies with the most foreign subsidiaries are OMV Petrom SA (9 subsidiaries) and Romcarbon SA (3 subsidiaries).

\section{Analysis of other related parties}

International Accounting Standard IAS 24 Related Party Disclosures states that a related party can be both a legal entity and an individual who is related to the entity (Deloitte, 2015). In our study, we analyse only legal entities.
From the analysis of the information provided in the financial statements reported by the companies in the sample, we identified a number of 312 foreign related companies. We mention that in these related parties we have not included the shareholders and subsidiaries of companies listed on BSE because they were analysed separately previously. 
From all the 312 foreign related companies, there are 46 affiliated companies in tax havens that have been declared in the financial statements. This means that only $14.74 \%$ are in tax havens. We notice that most of these companies are resident in Switzerland (15), Isle of Man (5), British Virgin Islands (4), Gibraltar (4) and Netherlands (4). While Cyprus is the tax haven in which are incorporated the most shareholders (18) and subsidiaries (2), in what concerns the related parties this country is only on the $6^{\text {th }}$ place. We also notice a big difference regarding the number of related parties between Switzerland and the rest of tax havens. Thus, of all affiliates in tax havens, 32.61\% are registered in Switzerland.

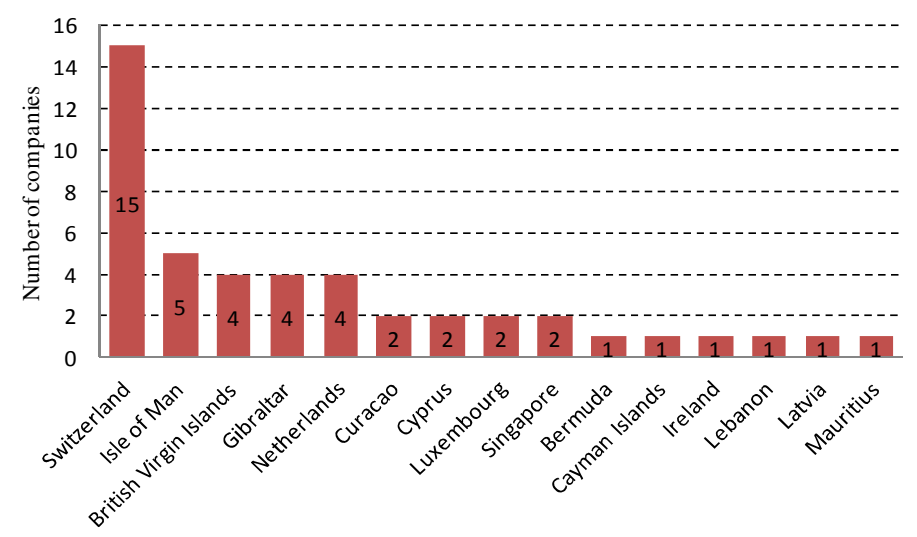

Figure 8: Top tax haven locations of other related parties of Romanian listed companies Source: own processing

\section{in 2013}

The companies in the sample with the most affiliates in tax havens are: OMV Petrom (9), BRD Groupe Société Générale (8) and Rompetrol Well Services (5).

\section{Key Findings and Results}

By compiling the results obtained from the analysis of shareholders, subsidiaries and other related parties, we reach the goal set.

Thus, of the 80 companies listed on the BSE, we found that 29 companies have links to tax havens in 2013 by shareholders, subsidiaries or other related parties.
The companies analysed have declared in the annual financial statements for 2013 a total of 386 foreign affiliates. Of these, 88 affiliated companies are registered in tax havens, representing $22.80 \%$.

Most of foreign related companies (without those in tax havens) are from Austria (64), Germany (27), France (24), Russia (16), Turkey (16) and Bulgaria (15) (see Figure 9). If we refer only to tax havens, Figure 10 shows that most related companies are in Cyprus (22), Switzerland (16), Netherlands (10), British Virgin Islands (8), Luxembourg (7) and Isle of Man (6). 


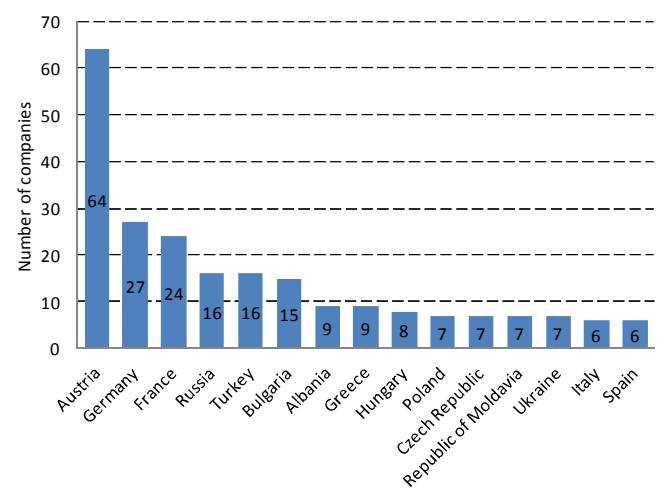

Fig 9. Top overseas non-tax haven locations of Romanian listed companies in 2013 Source: own processing

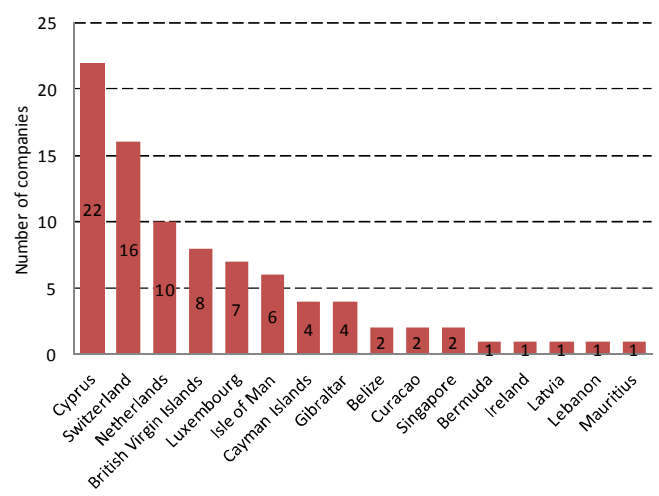

Fig 10. Top overseas tax haven locations of Romanian listed companies in 2013

Source: own processing

Most of foreign affiliates (without those in tax havens) belong to the following companies: OMV Petrom (95), BRD Groupe Société Générale (30), Zentiva (24), Voestalpine (23), Cos Targoviste (18), Rompetrol Rafinare (18) and Rompetrol Well Services (17) (see Figure 11).

The companies with the most related parties in tax havens are OMV Petrom (11), BRD Groupe Société Générale (8), Romcarbon (7), Rompetrol Well Services (7), Alro (5), Cos Târgovişte (5) and Zentiva (4) (see Figure 12).

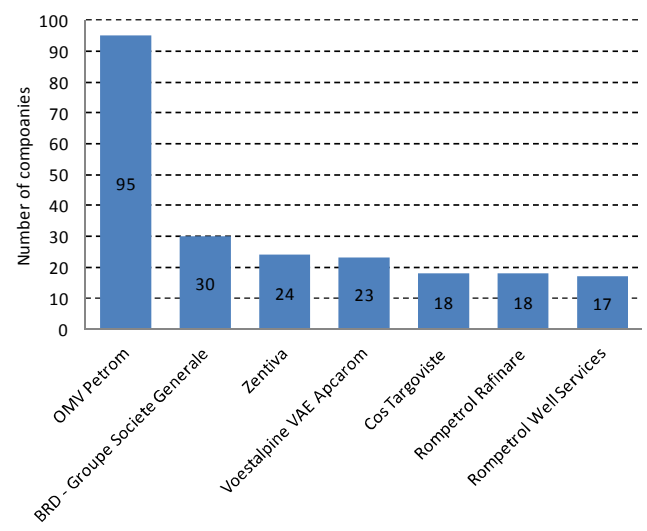

Fig 11. Top Romanian listed companies with overseas non-tax haven locations in 2013 Source: own processing

With the exception of BRD Groupe Société Générale which is operating in the financial sector, all other companies are operating in the industry sector (energy, metallurgy, chemical and pharmaceutical).

Limitations

The limitations of this study relate to the possible non-inclusion in the annual financial statements of all related parties.

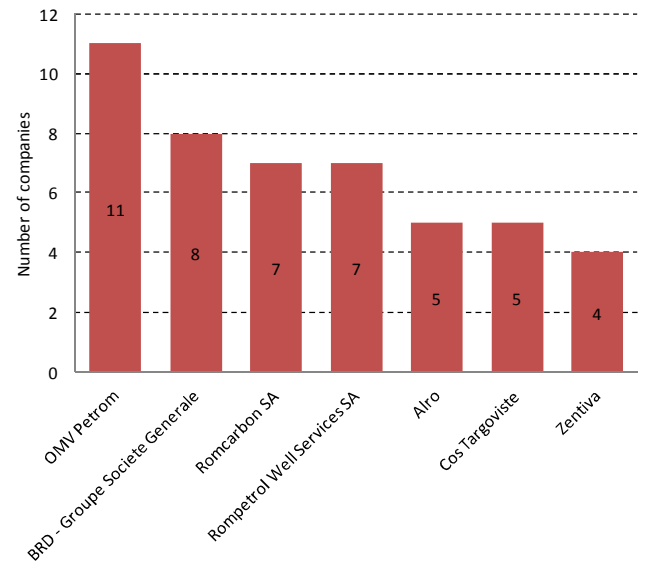

Fig 12. Top Romanian listed companies with overseas tax haven locations in 2013 Source: own processing

\section{Conclusions}

In Romania, the concerns regarding tax havens have become important in recent years. Although there are no statistics regarding the use of tax havens by individuals or legal entities, not even effective estimates were made in this respect. The only references in this sense may be the foreign direct investments. 
These aspects as well as the evidences of similar studies performed in USA, UK, France and Spain on the analysis of the use of tax havens by listed companies have been the main motivations to conduct this study.

Our research results show that 29 of the 80 listed companies (36\%) have links to 16 tax havens. Certainly, this is a relatively small percent compared to the situation registered in the United Kingdom (98\%), United States of America (82\%), France $(100 \%)$ and Spain (94\%), which confirms our hypothesis. Also, the differences are very high for the number of related companies as well. While in the UK the listed companies have 8492 affiliates in tax havens, in the USA 2686 affiliates, in France 1470 affiliates and in Spain 449 affiliates, the companies listed on the Bucharest Stock Exchange have only 88 affiliates in tax havens (38 shareholders, 4 subsidiaries and 46 other related companies). Most of the companies with links to tax havens are operating in the industry sector. However, we have to consider that few of the companies listed on the BSE are multinational. Another explanation may be that the Romanian State is a shareholder in 18 companies listed on the BSE, in 9 of them being the major shareholder. In addition, individual shareholders own a share of over $16 \%$ of the capital in the analysed companies.

There is also the possibility that the companies analysed by us have not included in the financial statements all their related parties. Moreover, we found that there is some lack of transparency in the annual financial statement, where some of the companies fail to mention all related parties and their country of origin if there were no transactions with them during the year.

Thus, we consider it absolutely necessary that the authorities impose on these companies the obligation to include in their annual financial reports a list of all related parties and their country of origin, even if transactions were not made. In addition, they should specify the amounts of transactions with each affiliated party separately, as well as the nature of the transaction.

\section{Acknowledgment}

This work was cofinanced from the European Social Fund through Sectoral Operational Programme Human Resources Development 2007-2013, project number POSDRU/159/1.5/S/142115 „Performance and excellence in doctoral and postdoctoral research in Romanian economics science domain".

\section{References}

1. ActionAid, (2011), "Addicted to tax havens: The secret life of the FTSE 100". [Online], [Retrieved January 5, 2015], http://www.actionaid.org.uk/sites/default /files/doc_lib/addicted_to_tax_havens.pdf

2. Brock, G. (2011), 'Reforms to global taxation and accounting arrangements as a means of pursuing global justice', Global Social Policy, 11 (1), 6-9.

3. Bucharest Stock Exchange, (2015), "Bucharest Stock Exchange Website". [Online], [Retrieved January 5, 2015], http://www.bvb.ro

4. Champpell, R. (1985) Secrets of offshore tax havens, ABM Publishing Co., Inglewood, California.

5. Chavagneux, C. and Rinuy, M-S., (2009), "Enquête exclusive : la présence des entreprises du CAC 40 dans les paradis fiscaux", Alternatives Economiques. [Online], [Retrieved January 5, 2015], http://www.alternatives-

economiques.fr/paradis-fiscaux---le-cac40et-les-paradis-fiscaux_fr_art_633

_42326.html

6. Cornez, A. (2000) The offshore money book: how to move assets offshore for privacy, protection and tax advantage, 2nd edition, Contemporary Publishing Group, Chicago.

7. Deloitte, (2015), "IAS 24 - Related Party Disclosures", IAS Plus. [Online], [Retrieved January 10, 2015], 
http://www.iasplus.com/en/standards/ias /ias24

8. Deneault, A. (2011) Offshore: tax havens and the rule of global crime, The New Press, New York.

9. Desai, M.A., Foley, C.F. and Hines Jr., J.R. (2005), 'Do tax havens divert economic activity?', Economics Letters, 90 (2), 219224.

10.Dharmapala, D. and Hines, J.R. (2006), 'Which countries become tax havens?', National Bureau of Economic Research, Working Paper 12802, 1-48.

11.Gravelle, J.G., (2015), "Tax havens: international tax avoidance and evasion", Congressional Research Service, CRS Report R40623. [Online], [Retrieved March 27, 2015],

https://www.fas.org/sgp/crs/misc/R4062 3.pdf

12.Hadnum, L. (2013) Tax planning with offshore companies and trusts, WPR Tax Publishing, Butschwil, Switzerland.

13.Hampton, M.P. and Christensen J. (2002), 'Offshore Pariahs? Small Island Economies, Tax Havens, and the Reconfiguration of Global Finance', World Development, 30 (9), 1657-1673.

14.International Monetary Fund, (2000), "Offshore Financial Center", IMF Background Paper. [Online], [Retrieved January 15, 2015], http://www.imf.org/external/np/mae/osh ore/2000/eng/back.htm

15.Johnson, J. and Holub, M. (2004), 'Stanley Works: to Bermuda or not to Bermuda, that was the question', Journal of Financial Crime, 11 (2), 186 - 194.

16.Killian, S. (2006), 'Where's the harm in tax competition? Lessons from US multinationals in Ireland', Critical Perspectives on Accounting, 17 (8), 10671087.
17.Kudrle, R.T. (2009), 'Did blacklisting hurt the tax havens?', Journal of Money Laundering Control, 12 (1), 33-49.

18.Larudee, M. (2009), 'Sourced of Polarization of Income and Wealth: Offshore Financial Centers', Review of Radical Political Economics, 41 (3), 343351.

19.Lesage, D. and McNaird, D. (2011), 'International cooperation against tax havens: Still a long way to go', Global Social Policy, 11 (1), 9-12.

20.Löpfe, P. and Vontobel, W. (2013) Multinaţionale bogate, cetăţeni săraci: profiturile exorbitante - soluţia imorală a marilor companii, Globo, Bucharest, Romania.

21.National Bank of Romania, (2013), "Exchange rate". [Online], [Retrieved January 10, 2015], http://www.bnr.ro/files/xml/nbrfxrates2 013.htm

22. Observatorio de Responsabilidad Social Corporativa, (2012), "La Responsabilidad Social Corporativa en las memorias anuales de las empresas del IBEX 35". [Online], [Retrieved January 10, 2015], http://observatoriorsc.org/laresponsabilidad-social-corporativa-en-lasmemorias-anuales-de-las-empresas-delibex-35/

23.0ECD (1998a), "Harmful tax Competition: An Emerging Global Issue", Organization for Economic Cooperation and Development, Paris.

24.OECD (1998b), "Economic Outlook", Organization for Economic Cooperation and Development, Volume 1998, Issue 1.

25.Palan, R., (2009), "The history of tax havens", History and Policy. [Online], [Retrieved January 12, 2015], http://www.historyandpolicy.org/papers/ policy-paper-92.html

26.Palan, R., Murphy, R. and Chavagneux, C. (2010) Tax havens: how globalization

Mihai-Bogdan Afrăsinei, Iuliana Eugenia Georgescu and Mircea Georgescu(2015),Journal of Eastern Europe Research in Business and Economics, DOI:10.5171/2015.187734 
really works, Cornell University Press, New York.

27.Preuss, L. (2010), 'Tax avoidance and corporate social responsability: you can't do both, or you can?', Corporate Governance, 10 (4), 365-374.

28.Preuss, L. (2012), 'Responsibility in Paradise? The adoption of CSR Tools by companies domiciled in tax havens', Journal of Business Ethics, 110 (1), 1-14.

29.Quintard, C. (2010), 'The need for European coordination on the future of tax bases in a globalised world', Transfer: European Review of Labour and Research, 16 (1), 29-35.

30.Shaxson, N. (2012) Treasure islands: uncovering the damage of offshore banking and tax havens, Palgrave Macmillan, New York.

31.Sikka, P. (2008), 'Globalization and its discontents: Accounting firms buy limited liability partnership legislation in Jersey', Accounting, Auditing \& Accountability Journal, 21 (3), 398-426.

32.Slemrod, J. and Wilson J.D. (2009), 'Tax competition with parasitic tax havens', Journal of Public Economics, 93 (11-12), 1261-1270.

33.Tax Justice Network, (2007), "Identifying Tax Havens and Offshore Finance Centres". [Online], [Retrieved January 12, 2015], 39. http://www.taxjustice.net/cms/upload/pd f/Identifying_Tax_Havens_Jul_07.pdf

34.The Economist, (2001), "A survey of the new rich: A taxing question". [Online], [Retrieved January 12, 2015], http://www.economist.com/node/654087

35.Smith, D., (2013), "Offshore Shell Games. The Use of Offshore Tax Havens by the Top 100 Publicly Traded Companies", U.S. Public Interest Research Groups. [Online], [Retrieved January 12, 2015], http://www.uspirg.org/sites/pirg/files/re ports/Offshore_Shell_Games_USPIRG.pdf

36.UNCTAD (2015), 'The fiscal role of multinational enterprises: towards guidelines for Coherent International Tax and Investment Policies', UNCTAD Investment and Enterprise Division, Working Paper 3/26/2015.

37.United States General Accounting Office (2004), International taxation: Information on Federal Contractors With Offshore Subsidiaries', Report to Congressional Requesters, GA0-04-293, Washington, D.C.

38.United States Government Accountability Office (2008), "International Taxation: Large U.S. Corporations and Federal Contractors with Subsidiaries in Jurisdictions Listed as Tax Havens or Financial Privacy Jurisdictions", Report to Congressional Requesters, GA0-09-157, Washington,

D.C. 